Wawasan:

Jurnal Kediklatan Balai Diklat Keagamaan Jakarta

PISSN: 2548-9232; ${ }_{\mathrm{E}}$ ISSN: 2775-3573

Volume 2 Nomor 1 Tahun 2021: 64-73

\title{
PENERAPAN METODE BERMAIN PERAN UNTUK MENINGKATKAN KEMAMPUAN BERBICARA PADA MATA PELAJARAN BAHASA ARAB SISWA KELAS IX E MTSN 1 SERANG
}

\author{
Ellyza Amin \\ Madrasah Tsanawiyah Negeri 1 Kota Serang \\ e-mail:ellyza.amin@gmail.com
}

\begin{abstract}
Speaking is one of four language-learning aspects. Based on experience, this aspect is difficult to develop because students are afraid to speak. However, the researchers tried to solve the problem by applying different learning methods. The method chosen is role play. The researcher conducted action research by applying the role-play method to 32 IX E MTsN 1 Serang City students. The action research used the Kemmis-McTaggart model in two cycles. In the action research, the variables measured were the increase in students' speaking skills and opinions on applying the role-play method. The analysis results showed that the students' speaking ability increased from cycle I to cycle II, namely the average class result in the first cycle was $71.88 \%$. In the second cycle, the class average was $88.28 \%$, meaning an increase of $16.40 \%$. Thus, the researcher concludes that the role-play method can help students improve speaking skills in Arabic subjects. In addition, students generally stated that they were happy with the use of the role-play method.
\end{abstract}

Keywords: speaking skill, Arabic, role play.

\begin{abstract}
Abstrak
Salah satu asepek pada mata pelajaran Bahasa asing adalah kemampuan berbicara. Berdasarkan pengalaman aspek ini sulit untuk dikembankan karena para siswa seperti ketakutan untuk berbicara. Namun demikina peneliti mencoba untuk memecahkannya dengan menerapkan metode pembelajaran berbeda. Metode yang dipilih adalah role play. Untuk mengjicobanya peneliti melakukan penelitian tindakan dengan menerapkan metode role play kepada 32 peserta didik IX E MTsN 1 Kota Serang. Penelitian tindakan menggunakan pola Kemmis-McTaggart sebanyak dua siklus. Pada penelitian tindakan tersebut variabel yang diukur adalah peningkatan kemampuan berbicara dan pendapat peserta didik terhadap penerapan metode role play. Hasil analisis didapatkan bahwa kemampuan berbicara siswa mengalami peningkatan dari siklus I sampai siklus II, yaitu hasil rata-rata kelas pada siklus I sebesar $71.88 \%$ dan pada siklus II rata-rata kelas yaitu $88.28 \%$, artinya mengalami peningkatan sebesar $16.40 \%$. Dengan demikian peneliti menyimpulkan bahwa metode role play dapat membantu peserta didik untuk meningkatkan kemampuan berbicara dalam mata pelajaran Bahasa Arab. Selain itu peserta didik di akhir siklus pada umumnya menyataka bahwa mereka senang dengan penerapan metode role play.
\end{abstract}

Kata kunci: kemapuan berbicara; bahasa ara; role play 
Wawasan:

Jurnal Kediklatan Balai Diklat Keagamaan Jakarta

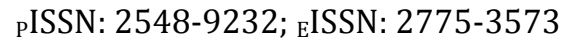

Volume 2 Nomor 1 Tahun 2021: 64-73

\section{PENDAHULUAN}

Kegiatan

pembelajaran merupakan proses pendidikan yang memberikan kesempatan kepada siswa untuk mengembangkan potensi mereka menjadi kemampuan yang semakin lama semakin meningkat dalam sikap, pengetahuan, dan keterampilan. Kompetensi tersebut diperlukan dirinya untuk hidup dan untuk bermasyarakat, berbangsa, serta berkontribusi pada kesejahteraan hidup umat manusia. Oleh karena itu, kegiatan pembelajaran diarahkan untuk memberdayakan semua potensi siswa menjadi kompetensi yang diharapkan.

Bahasa Arab adalah salah satu mata pelajaran di madrasah yang bertujuan untuk memfasilitasi para siswa memiliki keterampilan berbahasa asing. Bahasa Arab di madrasah dipersiapkan untuk pencapaian kompetensi dasar berbahasa, yang mencakup empat keterampilan berbahasa yang diajarkan secara integral, yaitu menyimak, berbicara, membaca, dan menulis. Meskipun begitu, pada tingkat pendidikan dasar dititikberatkan pada kecakapan menyimak dan berbicara sebagai landasan berbahasa (Direktorat Pendidikan Madrasah, 2007).

berbahasa yang penting dalam kehidupan sehari-hari setelah aktifitas mendengarkan. Berdasarkan bunyibunyi bahasa yang didengarkan, manusia belajar mengucapkan dan akhirnya mampu berbicara. Berbicara juga merupakan kemampuan mengungkapkan pendapat atau pikiran dan perasaan kepada seseorang atau kelompok secara lisan, baik secara berhadapan ataupun dengan jarak jauh. Moris dalam Novia (2002:54) menyatakan bahwa berbicara merupakan alat komunikasi yang alami antara anggota masyarakat untuk mengungkapkan pikiran dan sebagai sebuah bentuk tingkah laku sosial. Sedangkan, Wilkin dalam Maulida (2001:14) menyatakan bahwa tujuan pengajaran bahasa dewasa ini adalah untuk berbicara. Lebih jauh lagi Wilkin dalam Oktarina (2002:45) menyatakan bahwa keterampilan berbicara adalah kemampuan menyusun kalimatkalimat karena komunikasi terjadi melalui kalimat-kalimat untuk menampilkan perbedaan tingkah laku yang bervariasi dari masyarakat yang berbeda.

Keterampilan berbicara bahasa Arab merupakan salah satu dari keterampilan yang empat yang harus dikuasai anak didik ketika mengalami proses pembelajaran bahasa Arab (Ali Al-Auly: 1982). Berbicara bahasa Arab memiliki karekteristik yang berbeda dengan bahasa lainnya bila dilihat dari fungsinya sebagai alat komunikasi (multibahasa).

Seorang siswa belum dapat dikatakan menguasai bahasa Arab kalau belum menggunakan bahasa itu untuk berbicara walaupun mendapatkan nilai yang bagus dalam penguasaan kosakata dan tata bahasanya. Sekalipun diakui bahwa seseorang tidak akan mungkin dapat berbicara dengan bahasa Arab yang baik jika pengetahuan kosakata dan tata bahasanya rendah (Faisal Hendra: dalam Diklat, 2005).

Kegiatan berbicara sebenarnya merupakan kegiatan yang menarik dan ramai dalam kelas bahasa. Akan tetapi seringkali menjadi tidak menarik dan 
Wawasan:

Jurnal Kediklatan Balai Diklat Keagamaan Jakarta

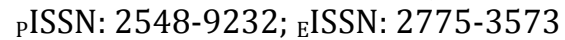

Volume 2 Nomor 1 Tahun 2021: 64-73

tidak merangsang partisipasi siswa sehingga membuat suasana menjadi kaku dan macet dikarenakan keterbatasan penguasaan kosakata dan tata bahasa. Namun demikian, kunci keberhasilan kegiatan tersebut sebenarnya ada pada guru. Apabila guru dapat memilih secara tepat topik pembicaraan yang sesuai dengan tingkat kemampuan siswa, dan memiliki kreatifitas dalam mengembangkan model-model pembelajaran berbicara yang banyak variasinya, tentu kemacetan tidak akan terjadi.

Hasil observasi awal di kelas IX E MTsN 1 Kota Serang diperoleh gambaran bahwa siswa masih banyak kurang terampil berbicara dengan bahasa Arab di lingkungan kelas dan madrasahnya. Berdasarkan hasil wawancara dengan beberapa orang siswa diperoleh gambaran bahwa mata pelajaran bahasa Arab masih dikategorikan mata pelajaran sulit dan membosankan karena banyak Nahwu dan Sharaf serta hapalan-hapalan lainnya yang kurang menyentuh kehidupan sehari-hari siswa. Dilihat dari nilai ulangan harian siswa kelas IX E MTsN 1 Kota Serang dalam mata pelajaran bahasa Arab yang hanya menunjukkan 9 siswa yang mampu mencapai Kriteria Ketuntasan Minimal (KKM) yaitu 75.

Berbagai usaha telah dilakukan guru dalam mengatasi permasalahan tersebut diatas, seperti melakukan diskusi atau tanya jawab dalam kelas dan membantu siswa yang mengalami kesulitan dalam belajar bahasa Arab. Tetapi usaha itu belum mampu merangsang siswa untuk aktif belajar dan berbicara bahasa Arab, karena siswa yang menjawab pertanyaan guru, cenderung didominasi oleh beberapa orang saja. Sedangkan siswa yang lainnya hanya mendengarkan dan mencatat informasi yang disampaikan temannya. Usaha yang dilakukan guru tampaknya belum membuahkan hasil yang optimal dalam meningkatkan kemampuan berbicara bahasa Arab siswa.

Permasalahan kemampuan berbicara siswa yang rendah perlu segera diatasi. Metode pembelajaran yang tepat sangat diharapkan untuk keefektifan pembelajaran.

Salah satu metode yang dapat digunakan untuk meningkatkan kemampuan berbicara adalah metode bermain peran (role play). Metode ini memungkinkan siswa untuk aktif dalam pembelajaran, mengembangkan pengetahuan, sikap, keterampilan kooperatif dan kemampuan berpikir kreatif. Selain itu juga memungkinkan terciptanya suasa kondusif bagi siswa dalam belajar, bekerjasama dengan teman, berinteraksi dengan guru sehingga pembelajaran bahasa Arab dapat berlangsung secara efektif.

Secara bahasa dalam kamus Bahasa Indonesia Balai Pustaka (1994) bermain peran adalah suatu aktifitas yang meniru aktifitas nyata yang ditemukan dalam kehidupan seharihari, lengkap dengan aktifitas gerak, aktifitas berbicara, mendengar dan merespon sesuatu, serta aktifitas berinteraksi dengan orang lain. Metode bermain peran juga merupakan salah satu proses belajar mengajar yang tergolong dalam metode simulasi yang merupakan suatu istilah umum yang berhubungan dengan menyusun dan mengoperasikan suatu model yang mengaplikasi proses-proses perilaku atau tingkah laku yang ditiru. 
Bermain peran atau role play adalah metode pembelajaran yang didalamnya terdapat perilaku purapura (berakting) dari siswa sesuai dengan peran yang telah ditentukan, dimana siswa menirukan situasi dari tokoh-tokoh sedemikian rupa dengan tujuan mendramatisasikan dan mengekspresikan tingkah laku, ungkapan, gerak-gerik seseorang dalam hubungan sosial antar manusia, Disamping itu metode bermain peran juga merupakan metode pembelajaran sebagai bagian simulasi yang diarahkan untuk mengkreasi peristiwa sejarah, actual, kejadian-kejadian yang muncul pada masa mendatang (Wina Sanjaya, 2006).

Metode bermain peran dapat menimbulkan pengalaman belajar, seperti kemampuan kerjasama, komunikatif, dan menginterpretasikan suatu kejadian, Melalui bermain peran, siswa mencoba mengeksplorasi hubungan-hubungan antar manusia dengan cara memperagakan dan mendiskusikannya, sehingga secara bersama-sama para siswa dapat mengeksplorasi perasaan-perasaan, sikap-sikap, nilai-nilai, dan strategi pemecahan masalah.

Dalam buku yang berjudul Cerdas di Kelas Sekolah Kepribadian karya Dr. Abdul Munir Mulkan (2002) dikatakan bahwa dalam permainan peran di kelas ada sembilan tahap yang dapat dipertimbangkan dalam melaksanakan pembelajaran di kelas, yaitu pemanasan kelompok, menentukan peran yang akan dilakukan, mengatur kelas sebagai setting, menyiapkan kelompok pengamat, memainkan peran, evaluasi, perbaikan dan generalisasi atau berbagi pengalaman.
Metode pembelajaran bermain peran penekanannya terletak pada keterlibatan emosinal dan pengamatan indera ke dalam suatu masalah yang secara nyata dihadapi. Murid diperlakukan sebagai subyek pembelajaran, secara aktif melakukan praktik-praktik berbahasa (bertanya dan menjawab) bersama temantemannya pada situasi tertentu. Tanpa disadari mempengaruhi proses psikologis yang tersembunyi, berupa sikap, nilai, perasaan dan sistem keyakinan, yang dapat diangkat ke taraf sadar melalui kombinasi pemeranan secara spontan. Dengan demikian para siswa dapat menguji sikap dan nilainya yang sesuai dengan orang lain, apakah sikap dan nilai yang dimilkinya perlu dipertahankan atau diubah (Mulyasa, E, 2005).

Sehubungan dengan itu penelitian melakukan sebuah penelitian tindakan kelas untuk mempelajari penerapan metode bermain peran untuk meningkatkan kemampuan berbicara pada mata pelajaran Bahasa Arab.

Rumusan masalah yang akan diteliti adalah sebagai berikut: Bagaimana peningkatan kemampuan berbicara siswa melalui penerapan metode bermain peran pada siswa kelas IX E MTsN 1 Kota Serang pada mata pelajaran bahasa Arab?

Penelitian ini diharapkan bermanfaat bagi siswa untuk dapat meningkatkan aktivitas dan hasil belajar pada keterampilan berbicara bahasa Arab serta sikap mereka yang termotivasi dalam mengikuti proses pembelajaran. Bagi guru dapat memberikan pengalaman dalam menerapkan metode pembelajaran yang dapat dipakai dalam upaya peningkatan mutu proses 
Wawasan:

Jurnal Kediklatan Balai Diklat Keagamaan Jakarta

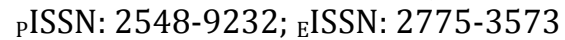

Volume 2 Nomor 1 Tahun 2021: 64-73

pembelajaran. Dan bagi sekolah/lembaga penelitian ini dapat meningkatkan suasana kegiatan pengembangan profesi guru di sekolah untuk mengumpulkan angka kredit pengembangan profesi guru.

\section{METODE}

Penelitian tindakan dilakukan pada siswa kelas IX E MTsN 1 Kota Serang pada mata pelajaran bahasa Arab Semester 1 tahun pelajaran 2015/2016.

Desain penelitian yang digunakan adalah Penelitian Tindakan Kelas (PTK) yang bertujuan untuk meningkatkan kemampuan berbicara siswa melalui metode bermain peran pada mata pelajaran bahasa Arab siswa kelas IX E MTsN 1 Kota Serang. Dalam PTK guru mengorganisasi kondisi praktek pembelajaran dan belajar dari pengalamannya sendiri, dapat mencobakan gagasan perbaikan dalam praktek pembelajaran mereka, dan melihat pengaruh nyata dari upaya itu (Wiraatmaja, 2006).

Berdasarkan rumusan masalah diatas, tujuan penelitian ini adalah mengetahui cara penerapan metode pembelajaran bermain peran yang benar untuk meningkatkan kemampuan berbicara siswa pada mata pelajaran bahasa Arab kelas IX E MTsN 1 Kota Serang tahun 2015.

Model penelitian tindakan yang digunakan adalah model Kemmis dan Taggaret (1998) dengan putaran siklus perencanaan, pelaksanaan tindakan, observasi/evaluasi, dan refleksi. Penelitian dimulai dari tahap pra survey hingga dilaksanakannya tindakan adalah 5 pekan. Sebagai tahap awal, dilakukan pra survei pada pekan kedua bulan Agustus 2015 dengan melakukan tes awal bebicara bahasa Arab materi perkenalan (التعارف) pada siswa kelas IX E MTsN 1 Kota Serang. Kemudian dilanjutkan dengan pemberian tindakan. Dan penelitian berakhir pada pekan kedua bulan September 2015.

Pelaksanaan penelitian yang dilakukan oleh peneliti melalui Siklus I yang terdiri dari perencanaan, tindakan dan pengamatan, dan reflksi dan pada Siklus II juga terdiri dari perencanaan, tindakan dan pengamatan, dan refleksi

Teknik pengumpulan data yang dilakukan dalam penelitian ini melalui observasi, angket, jurnal harian siswa dan lembar karya siswa. Data kuantitatif dianlisis menggunakan statistik deskriptif sedangkan data kualitatif dianalisis menggunakan metode analisis kualitatif melalui langkah pengkodean data, pengelompokan data, interpretasi dan penyimpulan.

Indikator

keberhasilannya penelitian dilihat dari 2 aspek. Pertama keberhasilan proses yang dilihat dari perkembangan proses pembelajaran. Kedua peningkatan kemampuan berbicara Bahasa Arab. Hal ini dilakukan dengan cara membandingkan kemampuan berbicara sebelum dan sesudah dilakukan tindakan pada tiap siklusnya dengan batas ketuntasan minimal (KKM) adalah 75. Selain itu, banyaknya siswa yang mendapat nilai kemampuan berbicara diatas KKM sebanyak lebih dari $80 \%$.

\section{HASIL DAN PEMBAHASAN Hasil Penelitian}

Sebelum melakukan penelitian, peneliti melakukan persiapanpersiapan yang berkaitan dengan 
Wawasan:

Jurnal Kediklatan Balai Diklat Keagamaan Jakarta

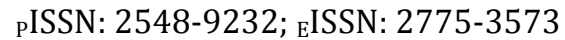

Volume 2 Nomor 1 Tahun 2021: 64-73

pelaksanaan penelitian. Langkah pertama adalah pemberian pretest kemampuan berbicara pada tanggal 12 Agustus 2015 dan perlakuan diberikan selama 4 kali pertemuan dan terbagi dalam 2 siklus. Siklus I dilaksanakan pada tanggal 19-26 Agustus 2015, sedangkan siklus II dilaksanakan pada tanggal 2-9 September 2015. Sebelum pelaksanaan tindakan kelas, peneliti memberikan penjelasan bahwa kegiatan pembelajaran yang akan dilakukan adalah kegiatan pembelajaran menggunakan metode bermain peran, yaitu dengan cara siswa memerankan masing-masing tokoh yang ada pada tema percakapan dengan memperagakannya dan mendemonstrasikannya didepan kelas secara berkelompok.

Hasil tes kemampuan berbicara sebelum adanya tindakan berdasarkan pretest yang diberikan adalah sebagai berikut:

Tabel 1 Hasil Tes pada Pra Tindakan/Siklus

\begin{tabular}{|c|c|c|c|c|}
\hline NO & KONDISI & FREKUENSI & PERSENTASE & RATAANTKP \\
\hline 1 & $\begin{array}{l}\text { Siswa yang } \\
\text { memperoleh } \\
\text { nilai } 275\end{array}$ & 14 & $43.75 \%$ & \multirow{2}{*}{67.91} \\
\hline 2 & $\begin{array}{l}\text { Siswa yang } \\
\text { memperoleh } \\
\text { Nilai< }<5\end{array}$ & 18 & $56.25 \%$ & \\
\hline & JUMLAH & 32 & $100 \%$ & \\
\hline
\end{tabular}

Tabel diatas menunjukkan bahwa kemampuan berbicara siswa sebanyak $43.75 \%$ telah tuntas belajar pada Kriteria Ketuntasan Minimal (KKM) yaitu 75. Hal ini berarti masih terdapat $56.25 \%$ siswa belum tuntas belajar. Sedangkan rata-rata tes kemampuan berbicara siswa pada pra penelitian tindakan kelas sebesar $55.35 \%$ yang berarti masih dibawah nilai batas KKM.

\section{Siklus I}

Dengan perencanaan tindakan, pelaksanaan tindakan, observasi dan evaluasi, penelitian ini dilaksanakan melalui tahap-tahap dalam metode bermain peran secara keseluruhan pada siklus pertama. Dan diakhir siklus diberikan tes akhir untuk mengetahui adanya peningkatan kemampuan berbicara siswa sebelum diberi perlakuan dan sesudah diberi perlakuan. Adapun hasil tes berbicara bahasa Arab siswa pada akhir siklus I disajikan pada tabel sebagai berikut:

Tabel 2 Hasil Tes Pada Siklus I

\begin{tabular}{|c|l|c|c|c|}
\hline NO & KONDISI & FREKUENSI & PRESENTASE & $\begin{array}{c}\text { RATAAN } \\
\text { TKP }\end{array}$ \\
\hline 1 & $\begin{array}{l}\text { Siswa } \\
\text { yang } \\
\text { mempero } \\
\text { leh } \\
\text { nilai } \geq 75\end{array}$ & 20 & $62.50 \%$ & \\
\hline 2 & $\begin{array}{l}\text { Siswa } \\
\text { yang } \\
\text { mempero }\end{array}$ & 12 & $37.50 \%$ & \multirow{2}{*}{76.75} \\
\hline $\begin{array}{l}\text { leh } \\
\text { Nilai }<75\end{array}$ & JUMLAH & 32 & $100 \%$ & \\
\hline & & & \\
\hline
\end{tabular}

Tabel diatas memberikan informasi bahwa adanyan peningkatan rata-rata hasil belajar siswa sebelum dan sesudah penelitian tindakan kelas menjadi 76.75 .

Jika dilihat dari indikator hasil pada rata-rata hasil tes kemampuan berbicara siswa menandakan bahwa masih sedikitnya siswa yang melampai batas ketercapaian ketuntasan. Hal ini dikarenakan rata-rata ketuntasan minimalnya yaitu 75. Juga pada siklus I masih terdapat 12 siswa yang belum memenuhi batas ketuntasan minimal meski rata-rata siswa yang tuntas masih pada taraf interval yang normal. Hal ini menunjukkan hasil yang belum optimal sehingga perlu diadakan kembali pembelajaran pada siklus II yang merupakan refleksi sebagai 
Wawasan:

Jurnal Kediklatan Balai Diklat Keagamaan Jakarta



Volume 2 Nomor 1 Tahun 2021: 64-73

tujuan melakukan evaluasi hasil tindakan penelitian yang telah dilakukan pada siklus I.

\section{Siklus II}

Dengan perencanaan tindakan, pelaksanaan tindakan, observasi dan Evaluasi, masih melalui proses pembelajaran metode bermain peran yang diterapkan secara keseluruhan dan diakhir siklus diberikan tes untuk mengetahui adanya peningkatan kemampuan berbicara siswa sebelum diberi perlakuan dan sesudah diberi perlakuan.

Adapun hasil tes berbicara bahasa Arab siswa pada akhir siklus II sebagaimana terlihat pada tabel berikut:

Tabel 3 Hasil Tes pada Siklus II

\begin{tabular}{|c|c|c|c|c|}
\hline NO & KONDISI & FREKUENSI & PRESENTASE & $\begin{array}{c}\text { RATAAN } \\
\text { TKP }\end{array}$ \\
\hline 1 & $\begin{array}{l}\text { Siswa yang } \\
\text { memperoleh } \\
\text { nilai } \geq 75\end{array}$ & 29 & $90.63 \%$ & \multirow{2}{*}{84.13} \\
\hline 2 & $\begin{array}{l}\text { Siswa yang } \\
\text { memperoleh } \\
\text { Nilai }<75\end{array}$ & 3 & $9.37 \%$ & \\
\hline & JUMLAH & 32 & $100 \%$ & \\
\hline
\end{tabular}

Berdasarkan tabel diatas, dapat diketahui bahwa siswa yang memperoleh nilai $\geq 75$ adalah sebanyak 29 siswa yang berarti $90.63 \%$ dari jumlah siswa sebanyak 32 orang. Sedangkan siswa yang memperoleh nilai $<75$ sebanyak 3 orang yang berarti $9.37 \%$, dengan rata-rata nilainya adalah 84.13. Secara klasikal hasil belajar berupa kemampuan berbicara siswa pada pembelajaran siklus II sudah mencapai target karena melebihi indikator yang ditetapkan $80 \%$.

Dan sebagai refleksinya data hasil observasi pada siklus II setelah diobservasi, menunjukkan bahwa selama pembelajaran dengan metode bermain peran pada siklus II tidak terdapat kendala yang berarti dan secara keseluruhan pelaksanaannya berlangsung dengan baik dan lancar. Hal ini dapat dilihat dari indikator keberhasilan hasil belajar dalam pembelajaran melalui metode bermain peran telah tercapai. Penilaian hasil belajar berupa rata-rata kemampuan berbicara mencapai 84.13 , yang berarti melebihi KKM yang sudah ditentukan yaitu 75 dengan siswa yang tuntas sebanyak 29 orang $(90.63 \%)$.

Pada akhir siklus pertama dan akhir siklus kedua disebarkan angket untuk mengetahui perasaan peserta didik emgenai penerapan metode role play. Angket terdri dari 2 komponen utama yaitu perasaan peserta ketika mengikuti pembelajaran menggunakan metode role play dan kendala yang dialami.

Pada akhir siklums pertama 17 dari 32 peserta didik $(53.15 \%)$ peserta didik kesulitan mengikutu pembelajaran dengan metode role play. Mereka menyatakan bahwa kedala mengikuti role play karena takut untuk berbicara. Di akhir siklus kedia hany 4 oarang saja $(12.50 \%)$ yang kesulitan mengikuti pembelajaran menggunakan metode role play dengan alasan yang reatif sama.

\section{Pembahasan}

Untuk mengetahui perubahan kemampuan berbricara pada peserta didik dilakukan tabulasi perbandingan. Perbandinga data-data yang diperoleh dari pra siklus, siklus 1 dan siklus 2 dapat dilihat pada tabel berikut ini: 
Wawasan:

Jurnal Kediklatan Balai Diklat Keagamaan Jakarta

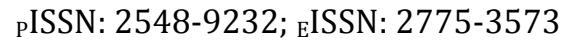

Volume 2 Nomor 1 Tahun 2021: 64-73

Tabel 4 Perbandingan Hasil Kemampuan Keterampilan Berbicara Siswa dengan Bermain Peran

\begin{tabular}{|l|l|l|l|}
\hline & PRASIKULUS & SKLLLS1 & SIKLLS2 \\
\hline $\begin{array}{l}\text { Persentasi peserta } \\
\text { didik yang mencepaal } \\
\text { KKM }\end{array}$ & 43.75 & 62.50 & 90.63 \\
\hline Rataratata skor & 67.91 & 76.75 & 84.13 \\
\hline
\end{tabular}

Berdasarkan tabel diatas telihat bahwa kemampuan keterampilan berbicara bahasa Arab siswa mengalami peningkatan. Siswa dinyatakan tuntas apabila nilai lebih dari ketuntasan Kriteria Minimal (KKM) yaitu 75. Indikator keberhasilan penelitian dapat dilihat dari peningkatan rata-rata kemampuan keterampilan berbicara siswa dari tiap siklusnya. Dari tabel rata-rata kemampuan keterampilan berbicara pada pra siklus adalah 67.91. Setelah adanya perlakuan pada siklus I diperoleh peningkatan rata-rata kemampuan keterampilan berbicara siswa menjadi 76.75. Dan meningkat juga setelah adanya perlakuan pada siklus II, diperoleh rata-rata kemampuan keterampilan berbicara meningkat menjadi 84.13.

Data-data

tersebut memperlihatkan bahwa metode role play berdampak terhadap peningkatan kemampuan berbicara.

Dengan demikian peneliti dan observer memutuskan kemampuan berbicara pada materi "peringatan perayaan Maulid Nabi Muhammad saw" meningkat melalui pembelajaran dengan menggunakan metode bermain peran, sehingga penelitian tindakan kelas diakhiri pada siklus II.
Selain dilihat dari indikator keberhasilan melalui peningkatan ratarata kemampuan berbicara siswa yang menandakan sebagai ketuntasan klasikal, indikator keberhasilan penelitian juga dilihat dari peningkatan ketuntasan secara individual dengan melihat dari banyaknya siswa yang tuntas pada tes kemampuan berbicara bahasa Arab siswa melebihi $80 \%$. Sebagaimana dilihat pada grafik berikut:

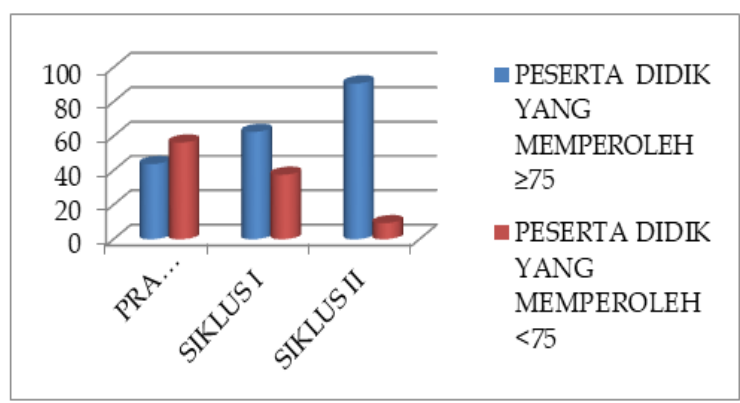

Grafik 1 Peningkatan Persentase Banyaknya Siswa yang Tuntas

Pada grafik diatas terlihat bahwa batang peserta didik yang memperoleh nilai kurang dari 75 mengalami penurunan dari pra siklus 56.25\%, siklus I $37.50 \%$, dan siklus II $9.37 \%$. Hal ini berimplikasi pada meningkat banyaknya siswa yang tuntas dari pra siklus sebanyak $43.75 \%$, siklus I $62.50 \%$ dan siklus II 90.63\%. Dengan demikian, terjadi peningkatan kemampuan penalaran siswa secara individual.

Bermain peran atau role play adalah metode pembelajaran yang didalamnya terdapat perilaku purapura (berakting) dari siswa sesuai dengan peran yang telah ditentukan, dimana siswa menirukan situasi dari tokoh-tokoh sedemikian rupa dengan tujuan mendramatisasikan dan mengekspresikan tingkah laku, ungkapan, gerak-gerik seseorang dalam hubungan sosial antar manusia. 
Wawasan:

Jurnal Kediklatan Balai Diklat Keagamaan Jakarta



Volume 2 Nomor 1 Tahun 2021: 64-73

Melalui kegiatan tersebut peserta didik dirangsang untuk mencoba membiasakan diri berbicara dalam Bahasa Arab.

Permasalahan untama belajar berbicara pada pembelajaran Bahasa asing adalah kurangnya ferekuensi pada untuk menyajikan latihan berbicara. Jadi sebenarnya masaha kesulitan berbicara pada siswa adalah karena tidak biasa. Oleh karena itu ketika guru merangsang para siswa untuk berbicara tanpa takut salah dan hanya berbicara dengan teman dengan diawali proses saling membetukan seperti pada role play yang disajika dalam penelitian tindakan ini maka sedikit-demi sedikit keberanian berbicara meningkat. Denga berkurangnya rasa takut untuk berbicara maka penyebab kesulitan telah berkurang dan para siswa mulai dapat berlatih berbicara lebih lancar.

Tentu saja pada kali pertama para siswa merasa kesulitan mengikuti pembelajaran berbicara dengan metode role paly seperti yang ditunjukkan oleh 17 orang peserta didik di siklus pertama. Mereka punya karakter pendiam sehingga takut untuk berbicara. Berbicara dengan teman dengan Bahasa sendiri saja jarang pembelajaran berlangsung. Apa lagi berbicara dalam bahasa asing. Namun demikian seiring dengan seringnya pembiasaan dan pembetulan maka rasa takut tersebut perlahan berkurang sehngga di akhir siklus hanya tinggal 4 orang saja yang masih menyatakan takut berbicara.

\section{KESIMPULAN}

Berdasarkan penelitian yang dilakukan di kelas IX E MTsN 1 Kota
Serang tahun pelajaran 2015 dan dari analisis data-data diperoleh kesimpulan bahwa kemampuan siswa berbicara dengan menggunakan metode bermain peran dapat meningkat dengan baik. Hal ini ditunjukkan dengan semakin meningkatnya rata-rata kemampuan berbicara bahasa Arab siswa dari pra siklus ke siklus I dan siklus II.

Berdasarkan angket, dapat diketehui bahwa siswa kelas IX E suka dan senang bila pembelajaran berbicara bahasa Arab menggunakan metode bermain peran karena dapat meningkatkan kemampuan berbicara siswa. Disamping itu, guru juga dapat mengembangkan inovasi dan kreatifitas dalam proses pembelajaran. Siswa juga perlu diberikan kemampuan untuk menerapkan bahasa Arab dalam kehidupan sehari-hari dimana guru sebaiknya melatih siswa sesering mungkin guna mengembangkan potensi siswa.

Berdasarkan hasil penelitian tersebut metode role play dapat dijadikan pertimbangan sebagai salah satu metode untuk pembelajaran berbicara. Tentu saja cara penerapannya dapat berbeda-beda sesuai dengan gaya megajar guru dan karakter peserta didik.

\section{Ucapan Terimakasih}

Alhamdulillah, dengan terselesainya penulisan jurnal ini, penulis mengucapkan terima kasih sebanyak-banyaknya kepada:

1. Kepala Madrasah Tsanawiyah Negeri 1 Kota Serang, Ibu Hj. Umi Kulsum Umayah, M. Pd. atas dukungan dan motivasinya. 
2. Kepala Tata Usaha MTsN 1 Kota Serang, Ibu Nining Yulianingsih atas dukungan dan motivasinya.

3. Ketua MGMP Bahasa Arab MTsN 1 Kota Serang, Ibu Hj. Sufroh yang sudah memberikan masukan dan motivasi untuk kenaikan golongan ini.

4. Rekan Guru MTsN 1 Kota Serang yang selalu memotivasi dan memberi banyak pencerahan atas tersusunnya jurnal ini.

\section{DAFTAR PUSTAKA}

Ainin, M, dkk. (2006). Evaluasi dalam Pembelajaran Bahasa Arab. Malang: Miskat.

Arikunto, Suharsimi. (2002). Prosedur Penelitian Suatu Pendekatan Praktis. Edisi Revisi, Jakarta.

Djamarah, Bahri, Saiful dan Azwar Zein. (1996). Strategi Belajar Mengajar. Jakarta: Rineka Cipta.

Depdiknas. (2002). Ringkasan Kurikulum dan Hasil Belajar, Jakarta: Pusat Kurikulum, Balitbang Depdiknas.

Direktorat Pendidikan Madrasah. (2007).

Fuad, Affendy. Metodologi Pengajaran Bahasa Arab. Malang: Misykat.

Hendra, Faisal. (2005). Metodologi Pembelajaran Bahasa Arab: Diklat Fasilitator Guru Bidang Studi Bahasa Arab Madrasah Tsanawiyah se-Indonesia, Jakarta.

Hidayat, D. (2003). Bahasa Lisan, bukan Bahasa Tulisan, untuk menciptakan biiah 'Arabiyah. Makalah, dibacakan pada Sem-lok "Pengembangan Pembelajaran Bahasa Arab di Madrasah", Jakarta.

Ibrahim dan Darsono. (2008). Fasih Berbahasa Arab I untuk Kelas IX Madrasah Tsanawiyah, Solo: PT. Tiga Serangkai Pustaka Mandiri.

Kamus Bahasa Indonesia. (1994). Balai Pustaka.

Matsna, Erta Mahyudin. (2012). Pengembangan Evaluasi dan Tes Bahasa Arab. Tangerang Selatan: Alkitabah.

Muhammad, Muhammad Abdul Khaliq. (1989). Ikhtibarat al-lughah. Riyadh: 'Imadah Su'un al-Maktabat-Jami'at al-Malik Sa'ud.

Munir, Mulkhan, Abdul. (2002). Cerdas di Kelas Kepribadian.

Ruestiyah. (1991). Strategi Belajar Mengajar. Jakarta: Rineka Cipta.

Sudjana, Nana. (2001). Penilaian Hasil Proses Belajar Mengajar. Bandung: PT. Remaja Rosdakarya.

Tarigan, Henry Guntur. (1990). Pengajaran Kompetensi Bahasa. Bandung: Angkasa. Usman, Uzer, Moh. (1995). Menjadi Guru Profesional. Bandung: Remaja Rosdakarya. Wahab, Muhbib Abdul. (2007). Metodologi Pembelajaran Bahasa Arab Yang Fun (Menyenangkan). Jakarta. 